\title{
The structure and toxicity of winter cyanobacterial bloom in a eutrophic lake of the temperate zone
}

\author{
Łukasz Wejnerowski ${ }^{1}$ Piotr Rzymski ${ }^{2} \cdot{\text { Mikołaj Kokociński }{ }^{1} \cdot \text { Jussi Meriluoto }}^{3}$
}

Accepted: 31 May 2018 / Published online: 22 June 2018

(c) The Author(s) 2018

\begin{abstract}
Winter cyanobacterial blooms have become increasingly common in eutrophic lakes advocating a need for their monitoring and risk assessment. The present study evaluated the toxicity of a winter cyanobacterial bloom in a eutrophicated freshwater lake located in Western Poland. The bloom was dominated by potentially toxic species: Planktothrix agardhii, Limnothrix redekei, and Aphanizomenon gracile. The toxin analysis revealed the presence of demethylated forms of microcystin-RR and microcystin-LR in ranges of 24.6-28.7 and 6.6-7.6 $\mu \mathrm{g} / \mathrm{L}$, respectively. The toxicity of sampled water was further evaluated in platelet-rich plasma isolated from healthy human subjects using lipid peroxidation and lactate dehydrogenase assays. No significant adverse effects were observed. The present study demonstrates that toxicity of some winter cyanobacterial blooms in the temperate zone, like that in Lubosińskie Lake, may not exhibit significant health risks despite microcystin production.
\end{abstract}

Keywords Aphanizomenon gracile $\cdot$ Cyanotoxins $\cdot$ Planktothrix agardhii $\cdot$ Toxicity $\cdot$ Winter cyanobacterial blooms

\section{Introduction}

Cyanobacterial blooms constitute a major threat for aquatic ecosystems, their commercial and recreational use, and human health. Their incidence in various world regions results not only from the increased input of nutrients (phosphorus or/and nitrogen) but also from the global climate changes including temperature rise, elevation of carbon dioxide level or increased salinity (for more details see Beardall and Raven 2004; Visser et al. 2016). The greatest threat exhibited by these blooms, particularly in lakes and drinking-water reservoirs, include the presence of toxic metabolites that can be released by intact cells or during cell lysis. Moreover, cyanobacteria can also produce odorants (Su et al. 2015) that can disqualify use of water resources. As estimated, toxigenic species are globally responsible for

Łukasz Wejnerowski

wejner@amu.edu.pl

1 Department of Hydrobiology, Faculty of Biology, Adam Mickiewicz University, Umultowska 89, 61-614 Poznań, Poland

2 Department of Environmental Medicine, Poznan University of Medical Sciences, Rokietnicka 8, 60-806 Poznań, Poland

3 Biochemistry, Faculty of Science and Engineering, Åbo Akademi University, Tykistökatu 6A, 20520 Turku, Finland approximately $75 \%$ of all cyanobacterial blooms (Maršálek et al. 2001; Bláhová et al. 2008).

In general, cyanotoxins constitute a very complex group of chemicals varying in their structures, physico-chemical properties, and exerted toxicity (Andersen et al. 1993; Sivonen and Jones 1999) that includes compounds such as hepatotoxic cyclic peptides (microcystins), cytotoxic alkaloids (cylindrospermopsins), teratogenic poly-methoxy-1alkenes, neurotoxic alkaloids (anatoxin and saxitoxin analogues) as well as components of their cell wall, e.g. lipopolysaccharides (Poniedziałek et al. 2012; Durai et al. 2015). Some cyanotoxins can bioaccumulate in aquatic organisms, cause organ alterations (Magalhães et al. 2001), and even lead to massive mortality of zooplankton (Zimba et al. 2006; Baumann and Jüttner 2008), fish (Jewel et al. 2003; Svirčev et al. 2016) and other aquatic biota (Krienitz et al. 2003).

In temperate zone, massive cyanobacterial blooms most commonly occur during summer and autumn although they were also recorded in spring and rarely, in winter (Simeunović et al. 2005; Toporowska et al. 2010; Ma et al. 2016). It is hypothesized that their occurrence during the coldest months may be driven by global warming and subsequent increase in water temperature (Paerl and Huisman 2008; Paerl et al. 2011). Moreover, some cyanobacteria species have a wide thermal tolerance and can persist under ice cover. This includes species from Planktothrix genus that were reported to maintain high abundance in eutrophic 
lakes during winter (Rücker et al. 1997; Legnani et al. 2005; Toporowska et al. 2010). In addition, species of this genus (e.g. P. agardhii or P. rubescens) are among the most toxigenic cyanobacteria, potent producers of various toxins including anatoxin-a, microcystins, and/or saxitoxins (Pomati et al. 2003; Metcalf and Codd 2014).

Winter cyanobacterial blooms can also be toxic. Jacoby et al. (1994) found anatoxins in the winter bloom of cyanobacterium Anabaena flos-aquae Brébisson ex Bornet \& Flauhault that occurred in Lake American in western Washington (USA). In turn, Ernst et al. (2001) observed a cytotoxic effect of microcystin-producing winter populations of $P$. agardhii (Gomont) Anagnostidis \& Komárek from lake in Germany on whitefish and larvae (Coregonus lavaretus). This considered, it is imperative to study whether all winter cyanobacterial blooms can exhibit ecological and health threats.

In the present study, we report the winter cyanobacterial bloom in a eutrophic freshwater lake in Western Poland. As revealed in previous research, the lake is dominated by toxic $P$. agardhii during the whole year (Mankiewicz-Boczek et al. 2009; Kobos et al. 2013). We hypothesized that (i) significant concentrations of toxins, particularly microcystins, may be present in water, and (ii) the bloom will exhibit a health threat due to the occurrence of the potent secondary metabolites. Therefore, the water samples were screened for the presence of microcystins, and their toxicity was evaluated by a method employing human platelet-rich plasma (PRP) with malondialdehyde (MDA) and lactate dehydrogenase (LDH) as markers of oxidative stress and cytotoxicity, respectively. This model was selected because platelets has been reported to be severely impacted during microcystin intoxications (Stoner et al. 1989; Giannuzzi et al. 2011; Rankin et al. 2013) while cyanotoxins, including microcystins, are known to induce lipid peroxidation leading to increase in MDA content and subsequent decrease in cellular viability marked by LDH leakage (Huang et al. 2015; Rzymski et al. 2017). Our study adds to toxicity assessment of cyanobacterial blooms that may occur in temperate zone during a winter period.

\section{Methods}

\section{Sampling}

Water samples were collected in January 2017 from Lake Lubosińskie $\left(52^{\circ} 31^{\prime} 40^{\prime \prime} \mathrm{N}, 1^{\circ} 22^{\prime} 56^{\prime \prime} \mathrm{E}\right)$ for physicochemical analyses, phytoplankton analysis, toxins analyses, and toxicological screening. Samples were taken using bathometer (UWITEC, Austria) from a surface layer $(10-50 \mathrm{~cm})$ under ice-cover $(10 \mathrm{~cm})$. Phytoplankton samples were fixed with Lugol's solution $1 \%$ and stored in darkness. Three sub-samples for toxin analyses were lyophilized immediately after sampling in the laboratory, and they were stored in the freezer at $-20{ }^{\circ} \mathrm{C}$. Samples for toxicity tests were filtered through $0.22 \mu \mathrm{m}$ syringeless filter devices and frozen at $-40{ }^{\circ} \mathrm{C}$ prior to analyses.

\section{Physico-chemical analyses}

Sampled water was a subject to physico-chemical analyses. The following parameteres were analysed: $\mathrm{pH}$, reduction-oxidation reaction (FiveEasy ${ }^{\mathrm{TM}}$ Benchtop Meter, Mettler Toledo, USA), electrical conductivity (Hanna Instruments, USA), dissolved oxygen $\left(\mathrm{O}_{2}\right.$, using the Winkler method), $\mathrm{NH}_{4}{ }^{+}$(using the Nessler method), nitrites $\left(\mathrm{NO}_{2}{ }^{-}\right.$, using the sulphanic acid method), nitrates $\left(\mathrm{NO}_{3}{ }^{-}\right.$, using the sodium salicylate method), TP (using the molybdate method after mineralization), ortophosphates (total reactive phosphorus, TRP, using the molybdate method), total iron (total $\mathrm{Fe}$, using the $o$-phenanthroline method), calcium $\left(\mathrm{Ca}^{2+}\right.$, using titration method with standardized EDTA solution), total hardness ( $\mathrm{TH}$, using the complexometric titration with EDTA), chloride $\left(\mathrm{Cl}^{-}\right.$, using the mercuric nitrate method) (APHA 2005). Inorganic nitrogen was calculated as a sum of $\mathrm{NH}_{4}^{+}, \mathrm{NO}_{2}^{-}$and $\mathrm{NO}_{3}{ }^{-}$; organic phosphorus $\left(\mathrm{P}_{\text {org. }}\right)$ was calculated by subtracting TRP from TP. The magnesium $\left(\mathrm{Mg}^{2+}\right)$ concentration $(\mathrm{mg} / \mathrm{L})$ was calculated from the equation:

$\mathrm{Mg}^{2+}$ concentration
$=\frac{\left(\text { Total hardness }\left(\mathrm{mg} \mathrm{CaCO}_{3} / \mathrm{L}\right)-2.497\right) \times \mathrm{Ca}^{2+} \text { concentration }(\mathrm{mg} / \mathrm{L})}{4.118}$

where 2.497 is the multiplying factor for $\mathrm{Ca}^{2+}$ as $\mathrm{CaCO}_{3}$ which is calculated by dividing the equivalent weight of $\mathrm{CaCO}_{3}$ to the equivalent weight of $\mathrm{Ca}^{2+}$, and 4.118 is the multiplying factor for $\mathrm{Mg}^{2+}$ as $\mathrm{CaCO}_{3}$ which is calculated by dividing the equivalent weight of $\mathrm{CaCO}_{3}$ to the equivalent weight of $\mathrm{Mg}^{2+}$ (APHA 2005).

\section{Phytoplankton analysis}

Prior analyses, phytoplankton samples were sedimented in 1-L glass cylinder for $48 \mathrm{~h}$, after which the overlying water was gently decanted off and lower layer (volume $20-40 \mathrm{~mL}$ ) was used for phytoplankton analysis. Species identification and counts were conducted using light microscope Olympus under $\times 400$ magnification. The phytoplankton enumeration was carried out in 100-150 fields of Fuchs-Rosenthal chamber, which ensured that at least 400 specimens were counted to reduce the error to less than $10 \%$. A single cell, a coenobium, or a filament represented one specimen in the analysis. The biovolume of each species was determined through a volumetric analysis of cells using geometric approximation and expressed as a wet weight following Wetzel and Likens (2000). 


\section{Toxin analyses}

Lyophilized water sub-samples were used to evaluate the presence or absence of three homologues of microcystins (MC-RR, -YR, -LR) and their demethylated forms using HPLC-diode-array UV detection (HPLC-DAD) and HPLCMS/MS analysis. Samples preparation and determination of microcystins were performed according to the previous description (Hautala et al. 2013).

\section{Toxicological screening}

Toxicity of sampled water was assessed using a model employing human blood collected from five healthy donors at the Regional Centre of Blood and Blood Treatment in Poznan, Poland, according to accepted safeguard standards and legal requirements in Poland. Blood samples from each donor were centrifuged at $200 \times g$ for $12 \mathrm{~min}$ to obtain platelet-rich plasma (PRP), divided into three groups:

(i) Group 1 (negative control group): $1 \mathrm{~mL}$ of PRP without any treatments;

(ii) Group 2 (positive control group): $1 \mathrm{~mL}$ of PRP incubated with $10 \mu \mathrm{M}$ of tert-butyl hydroperoxide ( $t$ BHP), a well-established inducer of oxidative stress and specifically, lipid peroxidation (Komosa et al. 2017; Poniedziałek et al. 2017);

(iii) Group 3 (treatment group): $1 \mathrm{~mL}$ of PRP incubated with $100 \mu \mathrm{L}$ of water sample filtered through $0.22 \mu \mathrm{m}$ syringeless filter devices.

All samples were incubated at $37^{\circ} \mathrm{C}$ for $1 \mathrm{~h}$. Following the incubation, oxidative stress and cytotoxicity were assessed. The former was based on concentration of MDA, a major product of lipid peroxidation (Ayala et al. 2014). Along with 4-hydroxy-2-nonenal, MDA is a major final product of this process, classically measured to assess the level of oxidative damage triggered by different toxins. Cells undergoing death release LDH rapidly to the extracellular environment, in which it remains relatively stable. For this reason, LDH is one of the most widely used markers of cytotoxicity (Fotakis and Timbrell 2006), and was also applied in our toxicological evaluation.

After incubation all samples were mixed on ice with 300 $\mu \mathrm{L}$ of RIPA Buffer $(50 \mathrm{mM}$ Tris-HCl, $\mathrm{pH} 7.4,1 \%$ Triton X$100,150 \mathrm{mM} \mathrm{NaCl}, 1 \%$ Tergitol-type NP-40, $0.5 \%$ sodium deoxycholate, $0.1 \%$ sodium dodecyl sulfate) to conduct the lysis of cellular component. RIPA buffer was supplemented with butylated hydroxytoluene (BHT) to prevent artificial lipid peroxidation. The samples were then centrifuged $\left(1600 \times g, 10 \mathrm{~min}, 4{ }^{\circ} \mathrm{C}\right)$ to remove insoluble material. The collected supernatants were used to determine the MDA using TBARS Assay Kit (Cayman Chemical, USA). Briefly, $100 \mu \mathrm{L}$ of each supernatant was mixed with $100 \mu \mathrm{L}$ of $10 \% \mathrm{C}_{2} \mathrm{HCl}_{3} \mathrm{O}_{2}$ and $800 \mu \mathrm{L}$ of working reagent: a mixture of thiobarbituric acid (TBA), acetic acid and $\mathrm{NaOH}$. The samples were then boiled for $1 \mathrm{~h}$ to accelerate formation of MDA-TBA adduct and the reaction was terminated by incubation on ice for $10 \mathrm{~min}$. After centrifugation (4500 rpm, $4{ }^{\circ} \mathrm{C}, 10 \mathrm{~min}$ ), $200 \mu \mathrm{L}$ of supernatant (in duplicate) was transferred to 96 -well plate. The absorbance of the product was read at $532 \mathrm{~nm}$. The calculated values were compared to a calibration curve prepared using MDA standard (Cayman Chemical, USA; $r^{2}=0.99$ ). results were expressed as $\mu \mathrm{M}$ of MDA.

Cytotoxicity was assessed using Cytotoxicity Detection LDH Kit (Sigma-Aldrich,Germany) according to the manufacturer's instructions. Following the incubation, all samples were centrifuged for $10 \mathrm{~min}$ at $1000 \mathrm{rpm}$ and supernatants $(100 \mu \mathrm{L})$ were transferred to 96 -well flat bottom microplate and mixed with $100 \mu \mathrm{L}$ reaction cocktail containing iodotetrazolium chloride, sodium lactate and diaphorase/NAD + mixture. After incubation $\left(30 \mathrm{~min}, 25^{\circ}\right.$ $\mathrm{C}$, darkness), the absorbance of each sample was read at $492 \mathrm{~nm}$, and cytotoxicity of lake water sample was calculated according to equation:

$$
\begin{aligned}
& \text { Cytotoxicity }[\%] \\
& =\frac{\text { Absorbance }(\text { sample })-\text { Absorbance }(\text { control })}{\text { Absorbance }(\text { high control })-\text { Absorbance }(\text { control })} \times 100
\end{aligned}
$$

where control is a non-exposed sample and high control represents a non-exposed sample mixed with RIPA lysis

Table 1 The physico-chemical parameters of water sampled and chlorophyll- $a$ concentration during winter cyanobacterial bloom at Lubosińskie Lake

\begin{tabular}{ll}
\hline Parameter & Measurement \\
\hline $\mathrm{pH}$ & 8.12 \\
Reduction-oxidation reaction $[\mathrm{mV}]$ & -63 \\
Temperature $\left[{ }^{\circ} \mathrm{C}\right]$ & 3 \\
Electrical conductivity $[\mu \mathrm{S} / \mathrm{cm}]$ & 511 \\
$\mathrm{O}_{2}[\mathrm{mg} / \mathrm{L}]$ & 5.5 \\
$\mathrm{TP}[\mathrm{mg} / \mathrm{L}]$ & 0.025 \\
$\mathrm{TRP}^{[\mathrm{mg} / \mathrm{L}]}$ & 0.0085 \\
$\mathrm{P}_{\text {org. }}[\mathrm{mg} / \mathrm{L}]$ & 0.0165 \\
$\mathrm{NH}_{4}{ }^{+}[\mathrm{mg} / \mathrm{L}]$ & 0.92 \\
$\mathrm{NO}_{2}{ }^{-}[\mathrm{mg} / \mathrm{L}]$ & 0.005 \\
$\mathrm{NO}_{3}{ }^{-}[\mathrm{mg} / \mathrm{L}]$ & 0.025 \\
$\mathrm{~N}_{\text {inorg. }}[\mathrm{mg} / \mathrm{L}]$ & 0.95 \\
$\mathrm{Cl}^{-}[\mathrm{mg} / \mathrm{L}]$ & 60 \\
$\mathrm{Ca}^{2+}[\mathrm{mg} / \mathrm{L}]$ & 47 \\
$\mathrm{Mg}^{2+}[\mathrm{mg} / \mathrm{L}]$ & 19.0 \\
$\mathrm{Total}^{\mathrm{Fe}}[\mathrm{mg} / \mathrm{L}]$ & 0.01 \\
$\mathrm{Total}^{2}$ hardness $[\mathrm{mg} \mathrm{CaCO} / \mathrm{L}]$ & 195.8 \\
$\mathrm{Chlorophyll}^{-a}[\mu \mathrm{mg} / \mathrm{L}]$ & 61.01 \\
\hline
\end{tabular}


buffer to evaluate the maximum releasable LDH activity for each sample.

\section{RESULTS}

\section{Physico-chemical analysis}

Physico-chemical analysis showed high concentrations of total phosphorus and ammonium indicating high trophic level of Lake Lubosińskie. Also chlorophyll- $a$ concentration, $\mathrm{pH}$ and conductivity values confirmed eutrophic character of this ecosystem. The physico-chemical parameters and chlorophyll- $a$ concentration of investigated lake are given in Table 1 .

\section{Phytoplankton analysis}

Total phytoplankton biomass exceeded $11 \mathrm{mg} / \mathrm{L}$ indicating eutrophic status of the lake. Phytoplankton community was dominated by cyanobacteria, which accounted for over $90 \%$ of total phytoplankton biomass (Fig. 1). P. agardhii was the most abundant species contributing over $50 \%$ to the total algae biomass. Other filamentous cyanobacteria, Limnothrix redekei and Aphanizomenon gracile, were also common species, the overall contribution of both taxa exceeded $22 \%$ and $6 \%$ of the total biomass, respectively. Other groups of algae were less abundant with the most numerous haptophyte Chrysochromulina parva (Fig. 1).

\section{Toxin analyses}

Both HPLC-DAD and HPLC-MS/MS revealed the absence of MC-RR, -YR, and -LR but the demethylated forms of MC-RR and MC-LR were present in each analysed water sub-sample from Lake Lubosińskie (Figs. 2 and 3). The concentration of demethylated MC-RR and demethylated MC-LR in lake water ranged from 24.6 to $28.7 \mu \mathrm{g} / \mathrm{L}$ and 6.6 to $7.6 \mu \mathrm{g} / \mathrm{L}$, respectively.
Fig. 1 Phytoplankton composition in Lubosińskie Lake during winter 2017: the biomass of organisms (a) and their abundance (b)

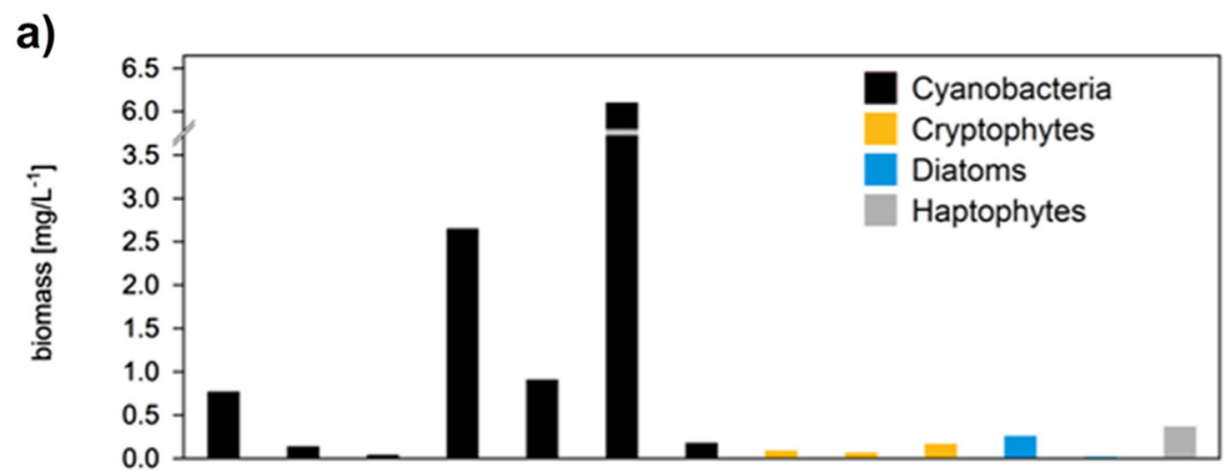

b)

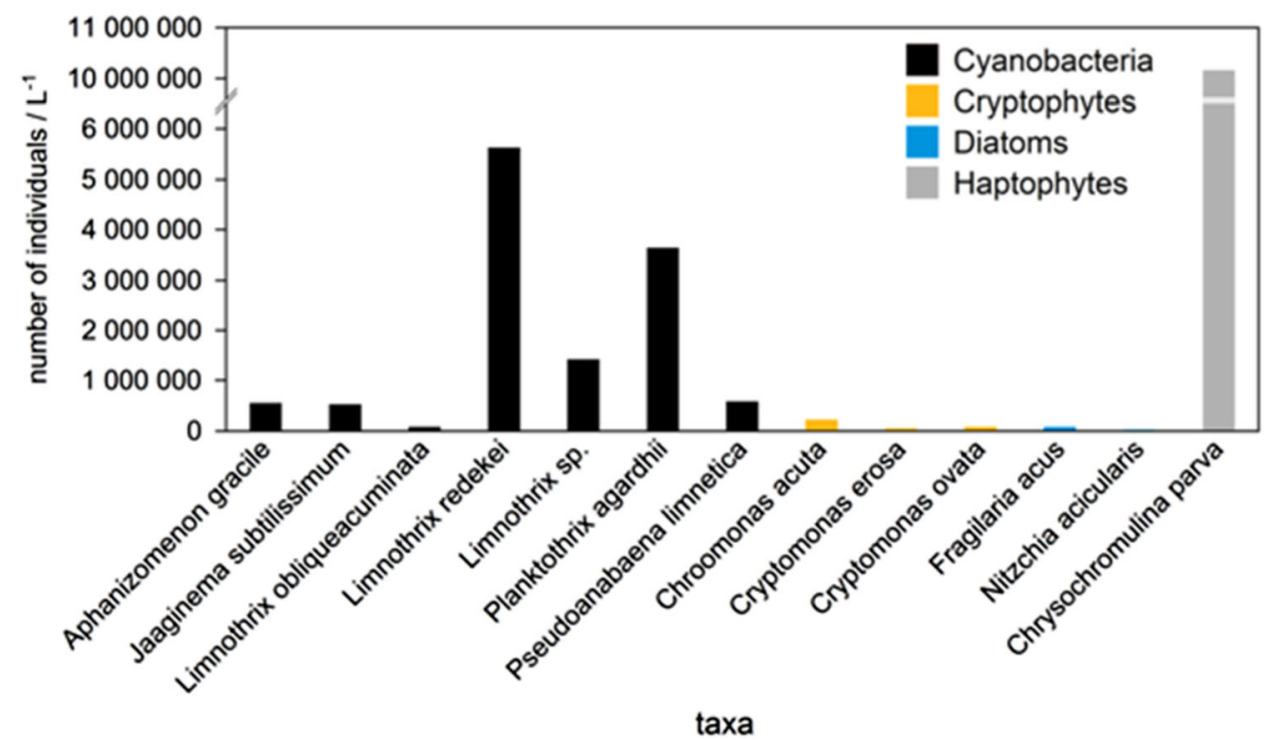




\section{Toxicological screening}

The mean \pm standard deviation content of MDA in human PRP treated with water samples $(13.9 \pm 1.7 \mu \mathrm{M})$ was only slightly and insignificantly increased compared to untreated control $(10.7 \pm 1.8 \mu \mathrm{M})$ supporting that no oxidative damage was induced despite relatively high volume of lake water $(1: 10, v-v)$ added to PRP. This was further confirmed by no significant cytotoxicity $(0.9 \pm 6.3 \%)$ as measured by LDH leakage assay (Fig. 4).

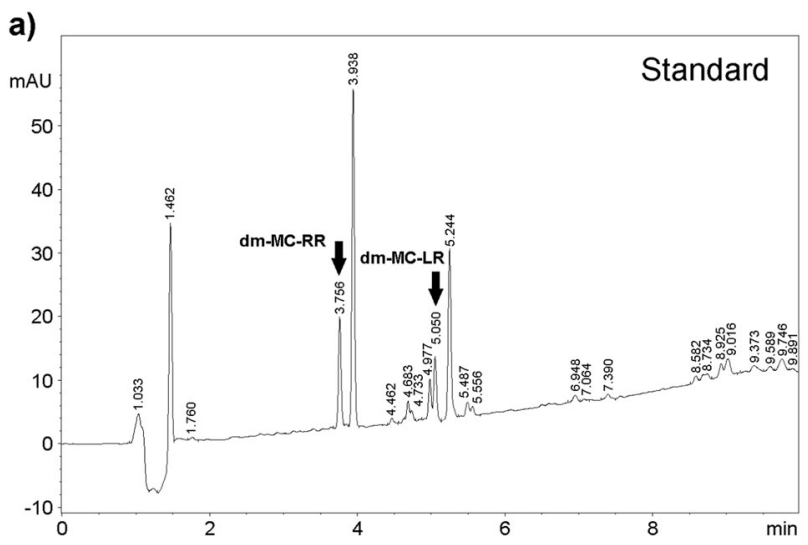

b)

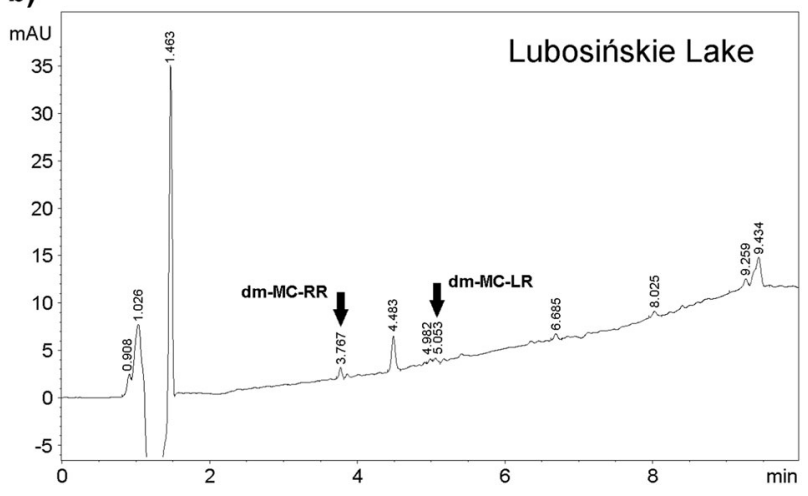

Fig. 2 The results of HPLC-DAD analysis: HPLC-UV chromatograms of MCs standard (a) and sample from Lubosińskie Lake (b)

\section{Discussion}

The present study demonstrates that toxicity of some winter cyanobacterial blooms in the temperate zone may not exhibit significant health risks even though this could be expected from the microcystin production. In the studied Lubosińskie Lake, the winter phytoplankton biomass was dominated by filamentous cyanobacteria including potentially toxic species $P$. agardhii, L. redekei, and A. gracile. Total biomass of all identified cyanobacteria species exceeded $90 \%$ of the total phytoplankton biomass indicating a hypertrophic status of the lake and the presence of winter cyanobaterial bloom. Moreover, chlorophyll- $a$ and nutrient concentration in the water indicated a high trophic status of the studied lake. Cyanobacterium $P$. agardhii, a common producer of microcystins (Fastner et al. 1999) contributed over $50 \%$ to the total phytoplankton biomass. Earlier study have showed perennial toxic blooms in this lake (Kokociński et al. 2009; Mankiewicz-Boczek et al. 2009; Kobos et al. 2013), and demethylated forms of microcystin-LR and microcystin-RR were found in this study. Numerous studies have shown that toxin production in cyanobacteria is slowed down at temperatures exceeding the optimal ranges (Codd and Ponn 1988; Lehtimäki et al. 1994; Rapala and Sivonen 1998). This is also supported by polar research performed by Kleinteich et al. (2012), which demonstrated that cyanobacterial diversity in the polar mats, share of toxin-producing cyanobacteria and cyanotoxins concentration increase over the temperature gradient.

The next part of our work was focused on the assessment of the toxicity of sampled water from Lake Lubosińskie using a model employing human blood. The use of human PRP derived from blood of healthy donors, and use of MDA and LDH as markers can be considered as a convenient and rapid method to evaluate toxicity of studied samples. It does not require complicated isolation steps/culturing, and responses are recorded in a rapid manner in the presence of some cellular and extracellular components of blood. This model provides a simplicity over specificity as an exact mechanism
Fig. 3 The results of HPLC-MS/ MS analysis: extracted ion chromatograms of $\mathrm{m} / \mathrm{z} 512.9$ (dm-MC-RR) and $\mathrm{m} / \mathrm{z}, 981.6$ (dm-MC-LR) of MCs standard and sample from Lubosińskie Lake
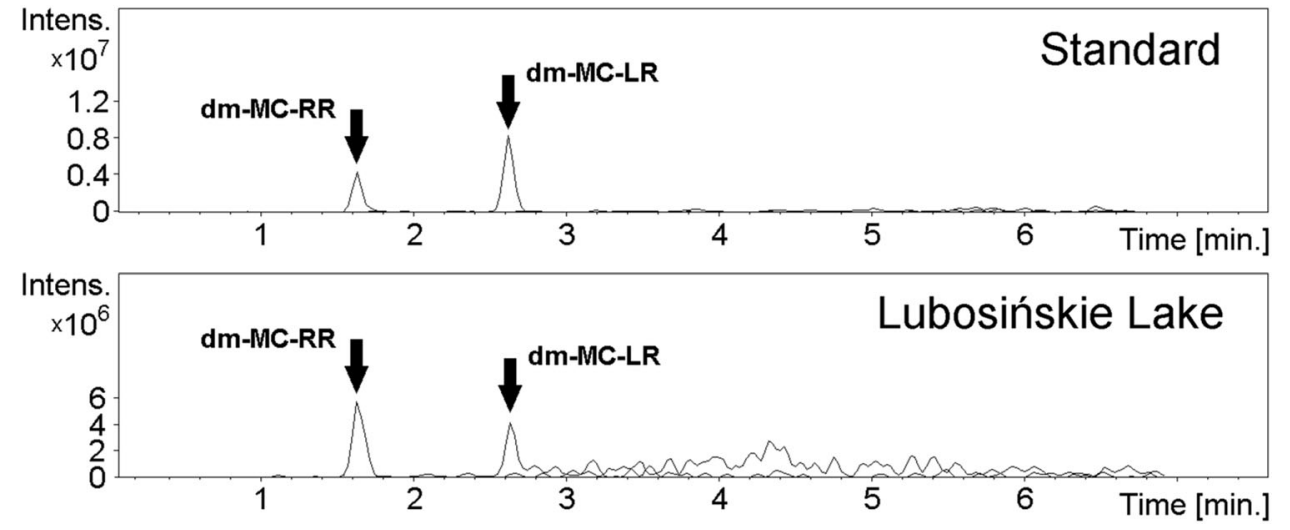


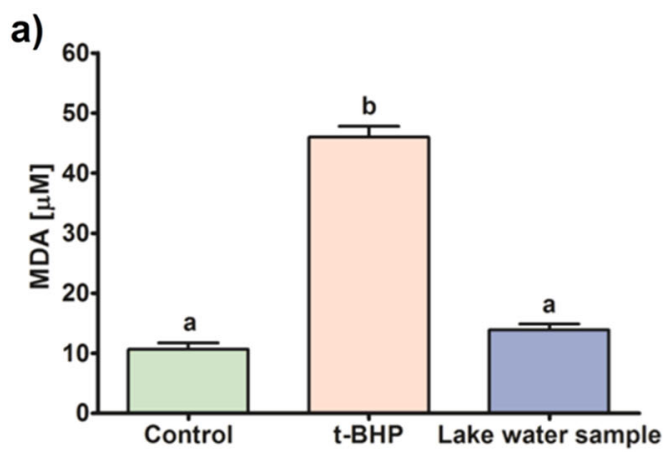

Fig. 4 The toxicological assessment of the filtered water from Lake Lubosińskie sampled during winter cyanobacterial bloom. Effects were measured in the human platelet-rich plasma (PRP) and compared to those exerted by tert-butyl hydroperoxide ( $t$-BHP; positive control). (a) The malondialdehyde (MDA) concentration (mean $\pm \mathrm{SD}$ ) as

of action and target cells cannot be established using this method. However it can be very useful in general screening for toxicity. Various cyanotoxins, including microcystins can induce oxidative stress and increase cellular content of MDA (Moreno et al. 2005; Rzymski et al. 2017). Based on this method, lake water samples were not found to exert any toxicity in employed in vitro model, indicating that the demethylated forms of microcystins at determined concentrations do not pose any major health threat.

Winter cyanobacterial blooms become more common phenomenon in lakes, what can be inferred from the increasing number of reports from the field surveys (Skulberg 1964; Willén and Mattsson 1997; Rücker et al. 1997; Ernst et al. 2001; Legnani et al. 2005; Simeunović et al. 2005; Toporowska et al. 2010; Babanazarova et al. 2013; Ma et al. 2016). Most common overwintering cyanobacteria in lakes are species of the genera Planktothrix and Limnothrix. Toporowska et al. (2010) found that P. agardhii filaments increase in length during autumn and it was interpreted as an adaptation to overwinter. On the other hand, a dominance of $P$. agardhii in lakes during winter may also be due to availability of ammonium, which occurs often in higher concentration during winter in lakes (Toporowska et al. 2010). This concept can be supported by the results of Donald et al. (2011), which revealed that availability of ammonium can favour non-heterocytous cyanobacteria over $\mathrm{N}_{2}$-fixers like nostocaleans. In support of this, in the present study we noted a relatively high ammonium concentration $(0.92 \mathrm{mg} / \mathrm{L})$. Furthermore, $P$. agardhii possesses a higher resistance against potential grazing zooplankton in comparison to number of other cyanobacteria associated with often distinctly wider filaments, covered on the surface by mucilaginous sheaths (Komárek and Komárková 2004; Wejnerowski et al. 2018).

A unique features of cyanobacteria, e.g. relatively low light and nutrient requirements (Tilzer 1987; Reynolds and Walsby 1975; respectively), wide thermal tolerance

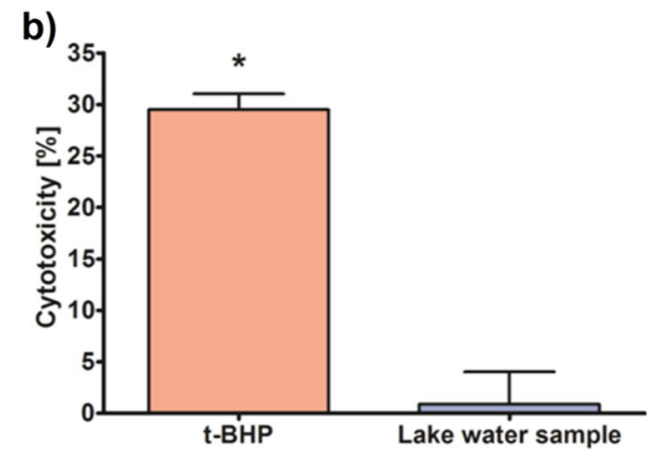

measured by TBARS assay $(n=5)$. Different superscript letters denote statistically significant difference $(p<0.05)$ according to Tukey's HSD test (MANOVA). (b) The cytotoxicity (mean $\pm \mathrm{SD}$ ) evaluated by means of lactate dehydrogenase (LDH) leakage. Asterisk indicates statistically significant difference with control $(p<0.05$; Student $t$-test $)$

(Robarts and Zohary 1987), buoyancy regulation (Reynolds et al. 1987) allow them to dominate the lake phytoplankton. High temperature, however, is frequently considered as a key factor determining the dominance and further expansion of cyanobacterial blooms (Paerl and Huisman 2008; Paerl et al. 2011). This is due to their optimum growth rates at higher temperature (Butterwick et al. 2005; Helbling et al. 2015). Moreover cyanobacteria show greater affinity for nutrients at elevated temperatures compared to eukaryotic algae (Xie et al. 2012). This study showed nonetheless, that some cyanobacteria including $P$. agardhii may benefit from low temperatures and sustain abundant population even beneath ice cover. Dominance of this cyanobacterium during low temperature, however, was not correlated with high toxins concentration, what is in line with recent findings of Walls et al. (2018). Therefore, it seems that winter blooms may pose serious threats for aquatic ecosystem due to high biomass production and phytoplankton community alteration but not always due to toxin production.

\section{Conclusions}

The present study reports a winter cyanobacterial bloom dominated by potentially toxic cyanobacteria, $P$. agardhii, $L$. redekei, and $A$. gracile. HPLC analyses revealed the presence of demethylated forms of MC-RR and MC-LR in the sampled lake water. Toxicological screening performed on sampled water using in vitro human cell model revealed that at these concentrations detected toxins are not likely to pose a health threat.

Acknowledgements LW is a beneficiary of National Science Centre in Poland scholarship for Ph.D. students No. UMO-2016/20/T/NZ8/ 00303.

Authors' contributions LW, PR and MK designed the study; LW drafted and finalized the manuscript; LW and JM performed HPLC 
analyses; PR performed physico-chemical analyses and toxicological screening; MK collected water samples and performed phytoplankton analysis; PR, MK and JM revised the manuscript.

\section{Compliance with ethical standards}

Conflict of interest The authors declare that they have no conflict of interest.

Open Access This article is distributed under the terms of the Creative Commons Attribution 4.0 International License (http://crea tivecommons.org/licenses/by/4.0/), which permits use, duplication, adaptation, distribution, and reproduction in any medium or format, as long as you give appropriate credit to the original author(s) and the source, provide a link to the Creative Commons license, and indicate if changes were made.

\section{References}

Andersen RJ, Luu HA, Chen DZ, Holmes CF, Kent ML, Le Blanc M, Taylor FJ, Williams DE (1993) Chemical and biological evidence links microcystins to salmon "netpen liver disease". Toxicon 31:1315-1323. https://doi.org/10.1016/0041-0101(93)90404-7

APHA, AWWA, WEF (2005) Standard methods for the examination of water and wastewater, 21st edn. APHA, AWWA, WEF, Washington, DC

Ayala A, Muñoz MF, Argüelles S (2014) Lipid peroxidation: production, metabolism, and signaling mechanisms of malondialdehyde and 4-hydroxy-2-nonenal. Oxid Med Cell Longev 2014:360438. https://doi.org/10.1155/2014/360438

Babanazarova O, Sidelev S, Schischeleva S (2013) The structure of winter phytoplankton in Lake Nero, Russia, a hypertrophic lake dominated by Planktothrix-like cyanobacteria. Aquat Biosyst 9:18. https://doi.org/10.1186/2046-9063-9-18

Baumann HI, Jüttner F (2008) Inter-annual stability of oligopeptide patterns of Planktothrix rubescens blooms and mass mortality of Daphnia in Lake Hallwilersee. Limnologica 38:350-359. https:// doi.org/10.1016/j.limno.2008.05.010

Beardall J, Raven JA (2004) The potential effects of global climate change on microalgal photosynthesis, growth and ecology. Phycologia 43:26-40. https://doi.org/10.2216/i0031-8884-43-1-26.1

Bláhová L, Babica P, Adamovský O, Kohoutek J, Maršálek B, Bláha L (2008) Analyses of cyanobacterial toxins (microcystins, cylindrospermopsin) in the reservoirs of the Czech Republic and evaluation of health risks. Environ Chem Lett 6:223-227. https:// doi.org/10.1007/s10311-007-0126-x

Butterwick C, Heaney SI, Talling JF (2005) Diversity in the influence of temperature on the growth rates of freshwater algae, and its ecological relevance. Freshw Biol 50:291-300. https://doi.org/10. 1111/j.1365-2427.2004.01317.x

Codd GA, Ponn GK (1988) Cyanobacterial toxins. Proc Phytochem Soc Eur 28:283-296

Donald DB, Bogard MJ, Finlay K, Leavitt PR (2011) Comparative effects of urea, ammonium, and nitrate on phytoplankton abundance, community composition, and toxicity in hypereutrophic freshwaters. Limnol Oceanogr 56:2161-2175. https://doi.org/10. 4319/lo.2011.56.6.2161

Durai P, Batool M, Choi S (2015) Structure and effects of cyanobacterial lipopolysaccharides. Mar Drugs 13:4217-4230. https:// doi.org/10.3390/md13074217

Ernst B, Hitzfeld B, Dietrich B (2001) Presence of Planktothrix sp. and cyanobacterial toxins in lake Ammersee, Germany and their impact on whitefish (Coregonus Lavaretus L.). Environ Toxicol 16:483-488. https://doi.org/10.1002/tox.10006.abs

Fastner J, Erhard M, Carmichael WW, Sun F, Rinehart KL, Rönicke H, Chorus I (1999) Characterization and diversity of microcystins in natural blooms and strains of the genera Microcystis and Planktothrix from German freshwaters. Arch Hydrobiol 145:147-163. https://doi.org/10.1127/archiv-hydrobiol/145/1999/ 147

Fotakis G, Timbrell JA (2006) In vitro cytotoxicity assays: comparison of LDH, neutral red, MTT and protein assay in hepatoma cell lines following exposure to cadmium chloride. Toxicol Lett 160:171-177. https://doi.org/10.1016/j.toxlet.2005.07.001

Giannuzzi L, Sedan D, Echenique R, Andrinolo D (2011) An acute case of intoxication with cyanobacteria and cyanotoxins in recreational water in Salto Grande Dam, Argentina. Mar Drugs 9:2164-2175. https://doi.org/10.3390/md9112164

Hautala H, Lamminmäki U, Spoof L, Nybom S, Meriluoto J, Vehniäinen M (2013) Quantitative PCR detection and improved sample preparation of microcystin-producing Anabaena, Microcystis and Planktothrix. Ecotoxicol Environ Saf 87:49-56. https:// doi.org/10.1016/j.ecoenv.2012.10.008

Helbling EW, Banaszak AT, Villafañe VE (2015) Global change feedback inhibits cyanobacterial photosynthesis. Sci Rep 5:14514. https://doi.org/10.1038/srep14514

Huang X, Chen L, Liu W, Qiao Q, Wu K, Wen J, Huang C, Tang R, Zhang $X$ (2015) Involvement of oxidative stress and cytoskeletal disruption in microcystin-induced apoptosis in CIK cells. Aquat Toxicol 165:41-50. https://doi.org/10.1016/j.aquatox.2015.05. 009

Jacoby JM, Gibbons HL, Hanowell R, Bouchard DD (1994) Wintertime blue-green algal toxicity in a mesotrophic lake. J Freshwat Ecol 9:241-251. https://doi.org/10.1080/02705060.1994. 9664891

Jewel MAS, Affan MA, Khan S (2003) Fish mortality due to cyanobacterial bloom in an aquaculture pond in Bangladesh. Pak J Biol Sci 6:1046-1050. https://doi.org/10.3923/pjbs.2003.1046.1050

Kleinteich J, Wood S, Küpper FC, Dietrich DR (2012) Temperaturerelated changes in polar cyanobacterial mat diversity and toxin production. Nat Clim Change 2:356-360. https://doi.org/10.1038/ NCLIMATE1418

Kobos J, Błaszczyk A, Hohfeld N et al. (2013) Cyanobacteria and cyanotoxins in Polish freshwater bodies. Oceanol Hydrobiol Stud 42:358-378. https://doi.org/10.2478/s13545-013-0093-8

Kokociński M, Dziga D, Spoof L, Stefaniak K, Jurczak T, Mankiewicz-Boczek J, Meriluoto J (2009) First report of the cyanobacterial toxin cylindrospermopsin in the shallow, eutrophic lakes of western Poland. Chemosphere 74:669-675. https://doi.org/10.1016/j.chemosphere.2008.10.027

Komárek J, Komárková J (2004) Taxonomic review of the cyanoprokaryotic genera Planktothrix and Planktothricoides. Czech Phycol 4:1-18

Komosa A, Rzymski P, Perek B, Ropacka-Lesiak M, Lesiak M, SillerMatula JM, Poniedziałek B (2017) Platelets redox balance assessment: current evidence and methodological considerations. Vasc Pharmacol 93-95:6-13. https://doi.org/10.1016/j.vph.2017. 06.002

Krienitz L, Ballot A, Kotut K, Wiegand C, Pütz S, Metcalf JS, Codd GA, Pflugmacher S (2003) Contribution of hot spring cyanobacteria to the mysterious deaths of lesser flamingos at Lake Bogoria, Kenya. FEMS Microbiol Ecol 43:141-148. https://doi. org/10.1111/j.1574-6941.2003.tb01053.x

Legnani E, Copetti D, Oggioni A, Tartari G, Palumbo MT, Morabito G (2005) Planktothrix rubescens' seasonal dynamics and vertical distribution in lake Pusiano (North Italy). J Limnol 64:61-73. https://doi.org/10.4081/jlimnol.2005.61 
Lehtimäki J, Sivonen K, Luukkainen R, Niemelä SI (1994) The effects of incubation-time, temperature, light, salinity, and phosphorus on growth and hepatotoxin production by Nodularia strains. Arch Hydrobiol 130:269-282

Ma J, Qin B, Paerl HW, Brookes JD, Hall NS, Shi K, Zhou Y, Guo J, Li Z, Xu H, Wu T, Long S (2016) The persistence of cyanobacterial (Microcystis spp.) blooms throughout winter in lake Taihu, China. Limnol Oceanogr 61:711-722. https://doi.org/10. 1002/lno.10246

Magalhães VF, Soares RM, Azevedo SMFO (2001) Microcystin contamination in fish from Jacarepaguá Lagoon (Rio de Janeiro, Brazil): ecological implication and human health risk. Toxicon 39:1077-1085. https://doi.org/10.1016/S0041-0101(00)00251-8

Mankiewicz-Boczek J, Gągała I, Kokociński M, Jurczak T, Stefaniak K (2009) Perennial toxigenic Planktothrix agardhii bloom in selected lakes of Western Poland. Environ Toxicol 26:10-20. https://doi.org/10.1002/tox.20524

Maršálek B, Bláha L, Turánek J, Neča J (2001) Microcystin-LR and total microcystins in cyanobacterial blooms in the Czech Republic 1993-2000. In: Chorus I (ed) Cyanotoxins-occurrence, causes, consequences. Springer, Berlin, pp. 56-62

Metcalf JS, Codd GA (2014) Cyanobacterial toxins (cyanotoxins) in water. Foundation for Water Research, Marlow, Buckinghamshire, UK, p 7

Moreno I, Pichardo S, Jos A, Gómez-Amores L, Mate A, Vazquez CM, Cameán AM (2005) Antioxidant enzyme activity and lipid peroxidation in liver and kidney of rats exposed to microcystinLR administered intraperitoneally. Toxicon 45:395-402. https:// doi.org/10.1016/j.toxicon.2004.11.001

Paerl HW, Huisman J (2008) Blooms like it hot. Science 320:57-58. https://doi.org/10.1126/science.1155398

Paerl HW, Hall NS, Calandrino ES (2011) Controlling harmful cyanobacterial blooms in a world experiencing anthropogenic and climate-induced change. Sci Total Environ 409:1739-1745. https://doi.org/10.1016/j.scitotenv.2011.02.001

Pomati F, Sacchi S, Rosetti C, Giovannardi S, Onodera H, Oshima Y, Neilan BA (2003) The freshwater cyanobacterium Planktothrix sp. FP1: molecular identification and detection of paralytic shellfish poisoning toxins. J Phycol 36:553-562. https://doi.org/ 10.1046/j.1529-8817.2000.99181.x

Poniedziałek B, Rzymski P, Kokociński M (2012) Cylindrospermopsin: water-linked potential threat to human health in Europe. Environ Toxicol Pharmacol 34:651-660. https://doi.org/ 10.1016/j.etap.2012.08.005

Poniedziałek B, Mleczek M, Niedzielski P, Siwulski M, Gąsecka M, Kozak L, Komosa A, Rzymski P (2017) Bio-enriched Pleurotus mushrooms for deficiency control and improved antioxidative protection of human platelets? Eur Food Res Technol. https://doi. org/10.1007/s00217-017-2921-3

Rankin KA, Alroy KA, Kudela RM, Oates SC, Murray MJ, Miller MA (2013) Treatment of cyanobacterial (microcystin) toxicosis using oral cholestyramine: case report of a dog from Montana. Toxins 5:1051-1063. https://doi.org/10.3390/toxins5061051

Rapala J, Sivonen K (1998) Assessment of environmental conditions that favor hepatotoxic and neurotoxic Anabaena spp. strains cultured under light limitation at different temperatures. Microb Ecol 36:181-192. https://doi.org/10.1007/s002489900105

Reynolds CS, Walsby AE (1975) Water blooms. Biol Rev 50:437-481. https://doi.org/10.1111/j.1469-185X.1975.tb01060.x

Reynolds CS, Oliver RL, Walsby AE (1987) Cyanobacterial dominance: the role of buoyancy regulation in dynamic lake environments. N Z J Mar Freshw Res 21:379-390. https://doi.org/10. 1080/00288330.1987.9516234

Robarts RD, Zohary T (1987) Temperature effects on photosynthetic capacity, respiration, and growth rates of bloom-forming cyanobacteria. N Z J Mar Freshw Res 21:391-399. https://doi. org/10.1080/00288330.1987.9516235

Rücker J, Wiedner C, Zippel P (1997) Factors controlling the dominance of Planktothrix agardhii and Limnothrix redekei in eutrophic shallow lakes. Hydrobiologia 342/343:107-115. https:// doi.org/10.1023/A:1017013208039

Rzymski P, Poniedziałek B, Mankiewicz-Boczek J, Faassen EJ, Jurczak T, Gaggała-Borowska I, Ballot A, Lürling M, Kokociński M (2017) Polyphasic toxicological screening of Cylindrospermopsis raciborskii and Aphanizomenon gracile isolated in Poland. Algal Res 24:72-80. https://doi.org/10.1016/j.algal.2017. 02.011

Simeunović J, Svirčev Z, Kristić S, Lazić L (2005) Occurrence of cyanobacterial blooms in Vojvodina water ecosystems. Geogr Pannonica 9:13-19

Sivonen K, Jones G (1999) Cyanobacterialtoxins. In: Chorus I, Bartram $\mathbf{J}$ (eds) Toxic cyanobacteria in water: a guide to public health significance, monitoring and management. E\&FN Spon, London, pp. $41-111$

Skulberg OM (1964) Algal problems related to the eutrophication of European water supplies, and a bioassay method to assess fertilizing influences of pollution on inland waters. In: Jackson DF (ed) Algae and man. Plenum Press, New York, NY, pp. 262-299

Stoner RD, Adams WH, Slatkin DN, Siegelman HW (1989) The effects of single L-amino acid substitutions on the lethal potencies of the microcystins. Toxicon 27:825-828. https://doi.org/10. 1016/0041-0101(89)90051-2

Su M, Yu J, Zhang J, Chen H, An W, Vogt RD, Andersen T, Jia D, Wang J, Yang M (2015) MIB-producing cyanobacteria (Planktothrix sp.) in a drinking water reservoir: distribution and odor producing potential. Water Res 68:444-453. https://doi.org/10. 1016/j.watres.2014.09.038

Svirčev Z, Obradowić V, Codd GA, Marjanović P, Spoof L, Drobac D, Tokodi N, Petković A, Nenin T, Simeunović J, Važić T, Meriluoto J (2016) Massive fish mortality and Cylindrospermopsis raciborskii bloom in Aleksandrovac Lake. Ecotoxicology 25:1353-1363. https://doi.org/10.1007/s10646-016$1687-\mathrm{x}$

Tilzer MM (1987) Light-dependence of photosynthesis and growth in cyanobacteria: implications for their dominance in eutrophic lakes. N Z J Mar Freshw Res 21:401-412. https://doi.org/10. 1080/00288330.1987.9516236

Toporowska M, Pawlik-Skowrońska B, Krupa D, Kornijów R (2010) Winter versus summer blooming of phytoplankton in a shallow lake: effect of hypertrophic conditions. Pol J Ecol 58:3-12

Visser PM, Verspagen JMH, Sandrini G, Stal LJ, Matthijs HCP, Davis TW, Paerl HW, Huisman J (2016) How rising $\mathrm{CO}_{2}$ and global warming may stimulate harmful cyanobacterial blooms. Harmful Algae 54:145-159. https://doi.org/10.1016/j.hal.2015.12.006

Walls JT, Wyatt KH, Doll JC, Rubenstein EM, Rober AR (2018) Hot and toxic: temperature regulates microcystin release from cyanobacteria. Sci Total Environ 610/611:786-795. https://doi.org/ 10.1016/j.scitotenv.2017.08.149

Wejnerowski Ł, Cerbin S, Wojciechowicz M, Jurczak T, Glama M, Meriluoto J, Dziuba M (2018) Effects of Daphnia exudates and sodium octyl sulphates on filament morphology and cell wall thickness of Aphanizomenon gracile (Nostocales), Cylindrospermopsis raciborskii (Nostocales) and Planktothrix agardhii (Oscillatoriales). Eur J Phycol. https://doi.org/10.1080/ 09670262.2018 .1442585

Wetzel RG, Likens G (2000) Limnological analyses. Springer-Verlag, New York, NY

Willén T, Mattsson R (1997) Water-blooming and toxin-producing cyanobacteria in Swedish fresh and brackish waters, 1981-1995. Hydrobiologia 353:181-192. https://doi.org/10.1023/A:100304 7019422 
Xie L, Rediske RR, Hong Y, O'Keefe J, Gillet ND, Dyble J, Steinman AD (2012) The role of environmental parameters in the structure of phytoplankton assemblages and cyanobacteria toxins in two hypertrophic lakes. Hydrobiologia 691:255-268. https://doi.org/ 10.1007/s10750-012-1077-1
Zimba PV, Camus A, Allen EH, Burkholder JM (2006) Co-occurrence of white shrimp, Litopenaeus vannamei, mortalities and microcystin toxin in a southeastern USA shrimp facility. Aquaculture 261:1048-1055. https://doi.org/10.1016/j.aquaculture.2006.08. 037 